\title{
PROMJENE U KEMIJSKOM SASTAVU I REOLOŠKIM SVOJSTVIMA PŠENICE TIJEKOM SKLADIŠTENJA
}

\author{
CHANGES IN CHEMICAL COMPOSITION AND RHEOLOGICAL \\ PROPERTIES OF WHEAT DURING STORAGE
}

\author{
Katarina Kurtović, Ana Matković, Karmen Jukić, Ž. Jukić
}

\section{SAŽETAK}

Pšenica (Triticum aestivum L.) je jedna od najvažnijih ratarskih kultura u Hrvatskoj. Nakon žetve, sprema se u skladišta u kojima ostaje do trenutka prerade u mlinske proizvode. Dokazano je, da je kakvoća pšenice nešto slabija odmah nakon žetve i da je potrebno da pšenica određeno vrijeme ostane uskladištena. To razdoblje koje se još naziva i posliježetveno dozrijevanje, traje različito za različite sorte. Tijekom tog razdoblja ali i tijekom skladištenja zrna pšenice do prerade, određeni čimbenici mogu pozitivno, ali i negativno utjecati na proteine, ugljikohidrate, lipide, hektolitarsku masu, svojstva mljevenja i reološka svojstva. Cilj ovog rada je korištenjem znanstvene literature prikazati koji čimbenici i na koji način utječu na promjenu ugljikohidrata, masti i proteina tijekom skladištenja pšenice te dinamiku poboljšanja reoloških svojstava pšenice od uskladištenja do početka prerade.

Ključne riječi: pšenica, posliježetveno dozrijevanje, reološka svojstva, kemijski sastav

\section{SUMMARY}

Wheat (Triticum aestivum L.) is one of the most important crops in Croatia. After harvest, it is stored in warehouses where it remains until the milling. It has been shown that the quality of wheat is somewhat weaker immediately after harvest and wheat must be stored for some time in the warehouses. This period, which is sometimes referred to as postharvest ripening, lasts differently for different varieties. During this period, but also during storage of wheat grain to processing, certain factors may positively or negatively affect proteins, carbohydrates, lipids, test weight, grinding properties and rheological properties. The aim of this paper is to present the factors that influence the change of carbohydrates, lipids and proteins 
Katarina Kurtović i sur.: Promjene u kemijskom sastavu i reološkim svojstvima pšenice tijekom skladištenja

during storage of wheat and the dynamics of improving the rheological properties of wheat from the storage to the start of processing.

Key words: wheat, postharvest maturation, rheological properties, chemical composition

\section{UVOD}

Pšenica je uz rižu i kukuruz, jedna od najvažnijih kultura u Svijetu. U 2016. godini, pšenica se u Svijetu uzgajala na 220,1 milijuna hektra, pri čemu je uz prosječni prinos od oko $3.4 \mathrm{t} / \mathrm{ha}$, proizvodnja zrna iznosila 749,4 milijuna tona (FAOSTAT, 2016.). Zrno pšenice i/ili škrob izoliran iz zrna pšenice koriste se u hranidbi životinja te u farmaceutskoj, tekstilnoj, prehrambenoj industriji, industriji papira te mnogim drugim industrijama. Međutim, najveći dio proizvodnje služi upravo za proizvodnju mlinskih proizvoda te za proizvodnju tjestenine, kruha i sličnih proizvoda (Shevkani i sur., 2016.; Heyne, 1987.; Dave R.H., 2008.). Posliježetveno dozrijevanje započinje odmah nakon žetve te se nastavlja u skladištu kroz određeno vrijeme gdje se, ovisno o temperaturi i relativnoj vlazi zraka u skladištu, odvijaju različiti biokemijski procesi u zrnu (Tomić i sur., 2013.). Čimbenici koji utječu na trajanje i kvalitetu posliježetvenog dozrijevanja zrna su: kultura (vrsta), genotip, relativna vlaga zraka, temperatura zraka u skladištu, mikoroorganizmi, insekti, svjetlost, disanje i prirodna enzimatska aktivnost u zrnu, te različiti uvjeti u objektima u kojima se skladišti pšenica (Baik i Donelson, 2018.; Niaz i sur., 2011.; Roberts, 1972.; Salunkhe i Deshpande, 1991.; Wang i Flores 1999.; Ritz, 1992.). Disanjem zrna mijenjaju se funkcionalna i nutritivna svojstva zrna, te se gubi suha tvar, a navedeno je pod utjecajem okolinskih uvjeta u skladištu (Karaoğlu i sur., 2010.). Više autora navodi kako pri povišenoj relativnoj vlazi i temperaturi u skladištu, dolazi do zagrijavanja mase koja je tada podložnija napadu gljivica, bakterija i insekata, a tada zrno propada te su gubitci u prinosu veliki. Također, može doći i do proklijavanja zrna te povećanja intenziteta disanja (Niaz i sur., 2011.; Sawant i sur., 2012.; Sorour i Uchnino, 2004.; FAO, 2011.; Kibar 2015.), što je objašnjeno na slici 1. Slika 1 prikazuje kako se smanjenom vlagom i temperaturom zrna stvaraju povoljni uvjeti za dugo/kratko skladištenje zrna, održava visoka kijavost zrna te se smanjuje rizik od pojave štetnika i plijesni. Cilj ovog rada je korištenjem znanstvene literature prikazati koji čimbenici i na koji način utječu na promjenu ugljikohidrata (škroba), proteina i masti tijekom skladištenja pšenice te na dinamiku poboljšanja reoloških svojstava pšenice od ulaska u skladišta do početka prerade. 
Katarina Kurtović i sur.: Promjene u kemijskom sastavu i reološkim svojstvima pšenice tijekom skladištenja

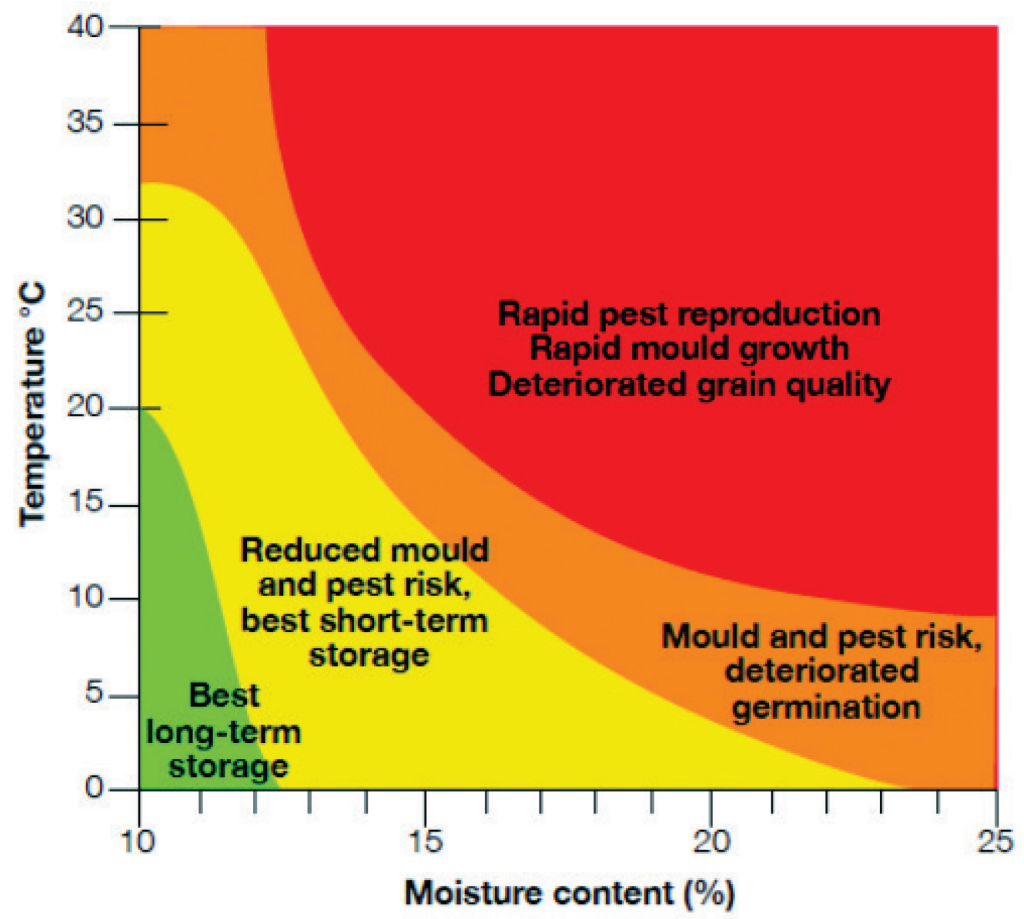

Slika 1. Utjecaj temperature i relativne vlage zrna tijekom skladištenja na kvalitetu zrna Figure 1 Influence of temperature and relative humidity of grain during storage on grain quality (Izvor: Grains Research \& Development Corporation, 2011. prilagođeno)

Promjene škroba tijekom skladištenja

Škrob je glavna komponenta zrna pšenice i pšeničnog brašna (Wang i Flores, 1999.). Tijekom dugotrajnog skladištenja pšenice $\alpha$ - i $\beta$ - amilaza mogu razgraditi škrob u dekstrine i maltozu (Wang i Flores, 1999.). Škrob pšenice sastoji se od otprilike 25\% amiloze i 75\% amilopektina (Sivam i sur., 2010.). Količina škroba u pšenici može varirati između 60 i 75\% od ukupne mase (Belderok i sur., 2000.). Razina šećera i škroba pri 14\% vlage malo se smanjuje zato što zrno pšenice disanjem proizvodi $\mathrm{CO}_{2}, \mathrm{H}_{2} \mathrm{O}$ i toplinu (Wang i Flores, 1999.). 
Katarina Kurtović i sur.: Promjene u kemijskom sastavu i reološkim svojstvima pšenice tijekom skladištenja

U istraživanjima Streleca i sur. (2010.), skladištenje zrna pšenice na povišenim temperaturama tijekom 360 dana rezultiralo je većinom smanjenjem sadržaja škroba za sortu Srpanjka (pri $25^{\circ} \mathrm{C}: 2 \%$, te pri $40^{\circ} \mathrm{C}: 5 \%$; $\mathrm{RH}=45 \%$ ) i Žitarka (pri $25^{\circ} \mathrm{C}$ : nema značajnog smanjenja škroba, pri $40^{\circ} \mathrm{C}: 3 \%$, $\mathrm{RH}=45 \%$ ), dok sorta Divana nije pokazala smanjenje škroba neovisno o temperaturama skladištenja. To je vjerojatno povezano s razlikama između sorata na razini endogenih antioksidansa kao što su karotenoidi, tokoferoli, reducirani glutation, dostupni cisteinski bočni lanci, askorbinska kiselina, polifenoli, flavonoidi i slobodne aminokiseline koje djeluju kao sredstvo za uklanjanje slobodnih radikala koji sprječavaju reakcije oksidacije i daljnju razgradnju škroba (Strelec i sur., 2010.). Pri povišenim temperaturama zraka $\left(45-50^{\circ} \mathrm{C}\right)$ i vlazi zrna $(>14 \%)$ zbog aktivnosti enzima $\alpha$ - i $\beta$ - amilaza koji razgrađuju škrob te zbog reakcije oksidacije/redukcije slobodnih radikala, tijekom posliježetvenog dozrijevanja dolazi do smanjenja škroba u zrnu pšenice. Međutim, ako je sadržaj vlage u sjemenu manji od $14 \%$, kao u navedenom pokusu, aktivnost $\alpha$ - i $\beta$ - amilaze trebala bi biti inhibirana (Strelec i sur., 2010.), stoga je vjerojatnije da su reakcije oksidacije i redukcije slobodnih radikala razlog smanjenja sadržaja škroba u pšenici (Strelec i sur., 2010.).

\section{Proteini}

Proteini su organske makromolekule sastavljene od velikog broja aminokiselina. Enzimi djeluju kao katalizatori za biokemijske procese i prema tome imaju važnu ulogu pri usladištavanju ratarskih proizvoda (Ritz, 1992.). Enzimatska je aktivnost ovisna o temperaturi (Peterson i sur., 2007.), stoga se kod povišenja temperature za $10^{\circ} \mathrm{C}$ ubrzava reakcija za 1-1.3 puta (Ritz, 1992.). Za sigurno skladištenje žitarica najvažnije su sljedeće skupine enzima: proteolitički enzimi koji hidroliziraju proteine (endopeptidaze) (Khademi, 1990.), amilaze (hidroliziraju škrob) (Horváthová i sur., 2000.), enzimi lipaze (hidroliziraju trigliceride) (Angelo i Ory, 1983.), peroksidaze (smanjuju vigor sjemena) (Corona-Carrillo i sur., 2014.). Ritz (1992.) navodi kako postoji malo povećanje proteina u zrnu pšenice tijekom dugotrajnog skladištenja, a autor to objašnjava rezultatom gubitka ugljikohidrata zbog disanja. Skladišni proteini zrna pšenice važni su za kvalitetu pšenice jer su odgovorni za neka reološka svojstva tijesta (elastičnost i rastezljivost), te na taj način određuju kvalitetu krajnjeg proizvoda (Rasheed i sur., 2014.). Mhiko (2012.) je zaključila kako je došlo do smanjenja količine proteina tijekom skladištenja neovisno o lokaciji skladišta. Sadržaj proteina prije skladištenja iznosio je $12.6 \%$, a uzorci su 
Katarina Kurtović i sur.: Promjene u kemijskom sastavu i reološkim svojstvima pšenice tijekom skladištenja

skladišteni tijekom pet mjeseci. Međutim, sadržaj proteina u uzorcima pšenice smanjivao se neovisno o lokaciji i uvjetima u skladištima. Najviša stopa smanjenja sadržaja proteina zabilježena je u uzorku pšenice gdje se sadržaj proteina s početnih $12.6 \%$ smanjio na $10.8 \%$. Najniža stopa smanjenja sadržaja proteina zabilježena je u uzorku pšenice gdje se sadržaj proteina s početnih $12.6 \%$ smanjio na $12.5 \%$. Autorica takvu degradaciju proteina objašnjava različitim uvjetima skladištenja unutar silosa, jer visoka temperatura i relativna vlaga zraka, zbog veće proteolitičke aktivnosti (enzimi peptidaze) unutar zrna, uzrokuju veće smanjenje proteina unutar zrna pšenice i obratno. Također, prema Mhiko (2012.), degradacija proteina može se prepisati i mogućem negativnom utjecaju plijesni na zrno, jer plijesni stvaraju mikotoksine odnosno aflatoksine, a aflatoksini za svoj rast i razvoj koriste hranjive tvari zrna, uključujući i proteine. Zhou i sur. (2003.) zaključili su kako su koncentracije prolamina i glutamina riže skladištene tijekom 16 mjeseci bile otprilike jednake neovisno o promjenama temperature skladištenja. Glutenski proteini čine 80 - $85 \%$ od ukupnog sadržaja proteina pšenice (Veraverbeke i Delcour, 2002.). Gluten je, sa svojim viskoelastičnim svojstvima, odgovoran za određena svojstva tijesta i za dobivanje kruha odgovarajućeg volumena'. Gluten indeks (GI) je jednostavna i brza metoda za određivanje kakvoće pšeničnog brašna i kvalitete glutena [slaba kvaliteta, GI $<30 \%$; normalna kvaliteta, GI $=30-80 \%$ i visoka kvaliteta, GI $>80 \%$; (Oikonomou i sur., 2015.; Ćurić i sur., 2001.)]. Brašna koja imaju GI od $60 \%$ do $90 \%$ smatraju se optimalnima za pekarsku industriju (Ćurić i sur., 2001.). Kvaliteta glutena povećava se na kraju razdoblja posliježetvenog dozrijevanja pšenice zbog formiranja i stabilizacije glutenskog kompleksa (Mezei i sur., 2007.). Kako povećanjem duljine skladištenja (tijekom 12 mjeseci) dolazi do smanjenja količine svježih proteina (Kibar, 2015.).

Vlažni gluten omogućuje kvantitativno mjerenje proteina koji tvore gluten u brašnu, a oni su odgovorni za svojstva pečenja i miješenja tijesta (Anjum i Walker, 2000; Karaoğlu i sur., 2010.). Postoje kontradiktorni literaturni podaci o sadržaju vlažnog glutena tijekom skladištenja. Mezei i sur. (2007.) su ispitivali četiri sorte pšenice te zaključili kako je, nakon 129 dana skladištenja, kod svih sorata došlo do manjeg povećanja (za 10\%) sadržaja vlažnog glutena pri temperaturi od $10-13^{\circ} \mathrm{C}$. Karaoğlu i sur. (2010.) zabilježili su smanjenje vlažnog glutena tijekom devet mjeseci skladištenja pšenice. Tijekom posliježetvenog

\footnotetext{
${ }^{1}$ https://www.grainscanada.gc.ca/fact-fait/gluten-eng.htm
} 
Katarina Kurtović i sur.: Promjene u kemijskom sastavu i reološkim svojstvima pšenice tijekom skladištenja

dozrijevanja i skladištenja pšenice, u zrnu dolazi do blagog povećanja vlažnog glutena, dok se kvaliteta (stabilnost) glutena poboljšala (Móré i sur., 2015.). Tijekom 5 mjeseci skladištenja zrna pšenice pri $50^{\circ} \mathrm{C}$ može doći do velikog smanjenja vlažnog glutena (Strelec i sur., 2010.). Strelec i sur. (2010) su otkrili kako se kod sorte Srpanjka, nakon 30 dana skladištenja sadržaj vlažnog glutena različito smanjivao ovisno o uvjetima temperature u skladištu $(\mathrm{RH}=45 \%$, pri $40^{\circ} \mathrm{C}$ : za $16 \%$, pri $25^{\circ} \mathrm{C} 4^{\circ} \mathrm{C}$ : za $5 \%$ ). Na slici 2. prikazan je pozitivan utjecaj količine vlažnog glutena u brašnu na volumen kruha.

Količina vlažnog glutena

\section{Wet gluten quantity:}

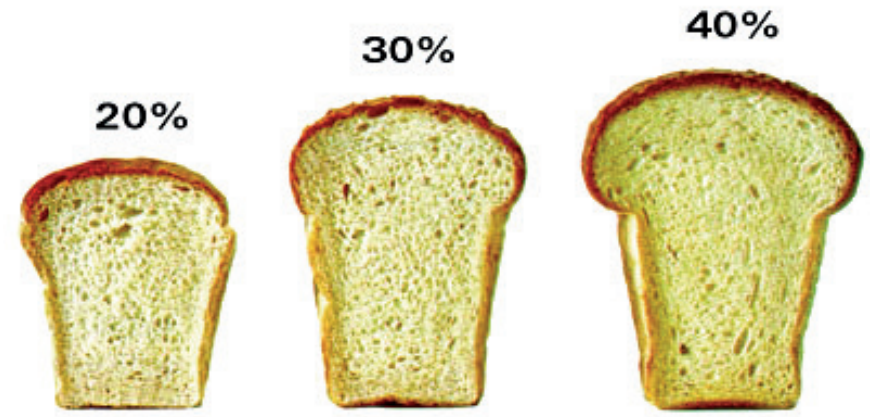

Slika 2. Utjecaj količine vlažnog glutena u brašnu na konačni volumen kruha

Figure 2 The effect of wet gluten quantity in flour on the final volume of bread (Izvor: http://www.aelab.co.za/index.php/perten/135')

Pekarska kvaliteta (volumen kruha) i određena reološka svojstva su pod utjecajem odnosa SH:SS (slobodni sulfhidrili:disulfidni mostovi) (Salmon, 1998.). Kako bi se osigurala optimalna reološka svojstva tijesta, potrebno je imati određenu količinu SH:SS izmjena između tiola niske molekularne mase (LMW) i glutenskih proteina (Cauvain, 2003.). Disulfidni mostovi (SS) su važni u stabilizaciji uvijajućih konformacija mnogih proteina (Shewry i Tatham, 1997.), dok postoje također i -SH skupine (slobodni sulfhidrili) (Delcour i sur., 2012.). S-S mostovi u cisteinu imaju veliku ulogu u razvoju meke sredine

\footnotetext{
${ }^{2}$ http://www.aelab.co.za/index.php/perten/135
} 
Katarina Kurtović i sur.: Promjene u kemijskom sastavu i reološkim svojstvima pšenice tijekom skladištenja

kruha, a njihov nedostatak uzrokuje probleme u kakvoći (Győri, 2005.). Specifičnim histokemijskim testovima za ispitivanje - $\mathrm{SH}$ grupe proteina utvrđeno je da se većina SH skupina proteina nalazi upravo u aleuronskom sloju i klici (Pomeranz, 1968.). Koncentracija -SH grupa proteina povećava se od sredine prema vanjskim slojevima endosperma. Omjer SS:SH grupa kontroliran genotipom, ali nije dokazan utjecaj okolinskih uvjeta. Također, kruh napravljen od zrna pšenice svih proteinskih klasa, imao je najbolji volumen kada je omjer SS:SH grupa bio 15:19 (Pomeranz, 1968.). Iako neka istraživanja ne pokazuju razliku između koncentracija glijadina i glutenina, druga istraživanja pokazuju kako se omjer SS:SH povećava skladištenjem pšenice, odnosno kako takva pšenica sadrži višu razinu glutenina, a nižu razinu glijadina (Wang i Flores, 1999.).

\section{Sedimentacijska vrijednost (SV)}

Hrušková i sur. (2004.) navode kako je tehnološka kvaliteta pšenice određena sadržajem i kvalitetom proteina, stupnjem oštećenosti škroba i koncentracijom amilaze. Parametri koji utječu na kvalitetu pšenice i krajnjih proizvoda određuju se standardnim metodama a to su, osim sadržaja proteina, broj padanja i sedimentacijska vrijednost (Hrušková i sur., 2004.). Sedimentacijska vrijednost (SV) je parametar kojim se može brzo odrediti pekarska kvaliteta brašna pšenice (Kibar, 2015.). Povećanje SV ukazuje na povećanje čvrstoće glutena i smanjenje njegove elastičnosti (Strelec i sur., 2010.). Na SV utječu količina glutena (sadržaj vlažnog glutena) i njegova kvaliteta, te rastezljivost glutena (Strelec i sur., 2010.). Kibar (2015.) je otkrio kako je SV pšenice bila ovisna o duljini skladištenja. Tako se SV tijekom 60 dana skladištenja malo povećavala, dok se tijekom 180 dana skladištenja smanjivala te je nakon 180 dana imala najmanju vrijednost. Prema istraživanju Streleca i sur. (2010.) utvrđeno je da se nakon godinu dana skladištenja pri temperaturi od $40^{\circ} \mathrm{C}$ i relativnoj vlazi zraka $45 \%$, smanjuje SV kod sorata Žitarke $(25 \%)$ i Divane (22\%), dok je kod Srpanjke porasla (23\%). Ephrat i Sinmena (1976.) navode da visoke temperature tijekom skladištenja $\left(30^{\circ} \mathrm{C}\right)$ imaju veći utjecaj na promjene u SV nego one niže. Tijekom četiri mjeseca skladištenja pšenice uočili su smanjenje sedimentacijske vrijednosti pšenice ovisno o temperaturi skladištenja $\left(4^{\circ} \mathrm{C}, 27^{\circ} \mathrm{C}\right.$ i $\left.37^{\circ} \mathrm{C}\right)$ (Hrušková i sur., 2004.). 
Katarina Kurtović i sur.: Promjene u kemijskom sastavu i reološkim svojstvima pšenice tijekom skladištenja

Broj padanja

Broj padanja (sec) definira se kao indikator aktivnosti $\alpha$-amilaze, te se pomoću tog parametra može otkriti i odrediti šteta uzrokovana klijanjem zrna pšenice prije žetve (tzv. klijanje zrna u klasu), a posljedica navedenog je nizak broj padanja (Kibar, 2015.; Ji i Baik, 2016.). Broj padanja ovisi o uvjetima koji vladaju u skladištu, temperaturi i vlazi zraka (Kibar, 2015.). Smatra se da je povećanje broja padanja pšeničnog zrna rezultat smanjenja aktivnosti $\alpha$-amilaze (Baik i Donelson, 2018.), međutim neka istraživanja to demantiraju (Salmon, 1998.).

Određena količina $\alpha$-amilaze je potrebna kako bih se dobio kruh s povoljnim svojstvima (slika 3 ). Kada je aktivnost $\alpha$-amilaze povoljna, tada se dobiva kruh velikog volumena $\mathrm{s}$ mekom teksturom (broj padanja $=250$ ). Kada je aktivnost $\alpha$-amilaze previsoka, tada se dobiva ljepljiva korica kruha i može doći do smanjenja volumena (broj padanja $=62$ ), a kod premale aktivnosti dobiva se suha kora kruha s moguće smanjenim volumenom (broj padanja $=400$ ).

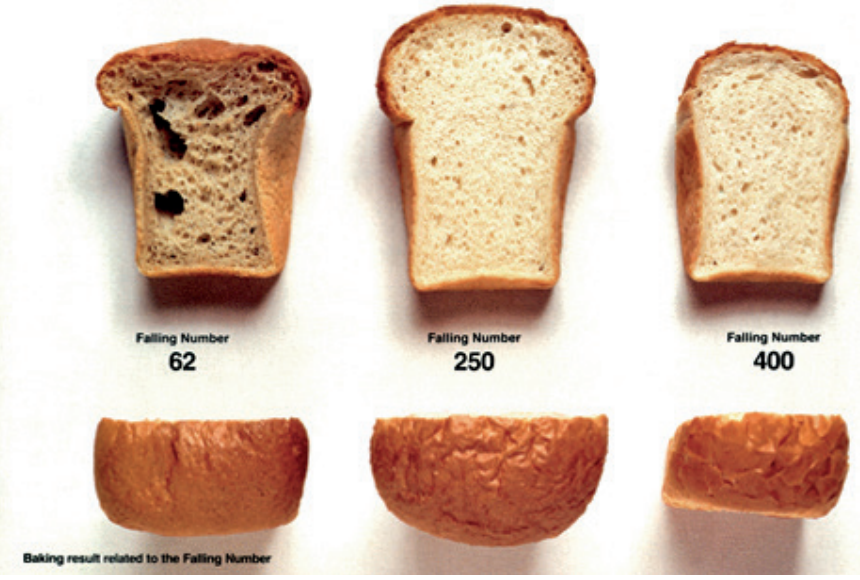

Slika 3. Utjecaj broja padanja na pečenje i karakteristike kruha

Figure 3 Effect of falling number on baking result and bread characteristics (Izvor:https://www.perten.com/Products/Falling-Number/Applications/ Flour-milling-and-baking $\beta^{3}$ )

\footnotetext{
${ }^{3}$ https://www.perten.com/Products/Falling-Number/Applications/Flour-milling-and-baking/
} 
Katarina Kurtović i sur.: Promjene u kemijskom sastavu i reološkim svojstvima pšenice tijekom skladištenja

Broj padanja kod pšenice se povećava tijekom skladištenja, a vrijednost povećanja ovisi o uvjetima koji vladaju tijekom skladištenja (Kibar, 2015.). $\mathrm{U}$ tablici 1. prikazana je promjena u broju padanja tijekom skladištenja kod različitih autora u literaturi, te se može primijetiti kako se broj padanja povećava odnosno smanjuje ovisno o duljini skladištenja i uvjetima koji su vladali u skladištu.

Tablica 1. Promjene u broju padanja tijekom skladištenja zrna pšenice

Tabel 1 Changes in the fall number during storage of wheat grain

\begin{tabular}{|l|c|c|c|c|}
\hline \multicolumn{1}{|c|}{ Autori } & $\begin{array}{c}\text { Karaoğlau i sur. } \\
(2010 .)\end{array}$ & $\begin{array}{c}\text { Mhiko } \\
(2012 .)\end{array}$ & $\begin{array}{c}\text { Baik i Donelson, } \\
(2018 .)\end{array}$ & $\begin{array}{c}\text { Baik i Donelson, } \\
(2018 .)\end{array}$ \\
\hline $\begin{array}{l}\text { Uvjeti i duljina } \\
\text { trajanja } \\
\text { skladištenja }\end{array}$ & $\begin{array}{c}\text { 3., 6. i 9. mjeseci } \\
\text { Temperatura: } \\
10,20 \mathrm{i} 30^{\circ} \mathrm{C} \\
\text { Vlaga zrna: } \\
12,14 \mathrm{i} 16 \%\end{array}$ & 5 mjeseci & $\begin{array}{c}\text { Temperature: } \\
35^{\circ} \mathrm{C}, 5^{\circ} \mathrm{C} \text { ili } 23^{\circ} \mathrm{C}\end{array}$ & $\begin{array}{c}\text { 2. tjedna, } \\
\text { i 26. tjedan } \\
\text { od žetve } \\
\text { do skladištenja }\end{array}$ \\
\hline $\begin{array}{l}\text { Promjene broja } \\
\text { padanja } \\
\text { tijekom } \\
\text { skladištenja }\end{array}$ & Povećanje & $\begin{array}{c}\text { Povećanje } \\
\text { ili smanjenje } \\
\text { (ovisno o uvjetima } \\
\text { skladištenja) }\end{array}$ & Povećanje & Povećanje \\
\hline
\end{tabular}

Promjene lipida

Pšenica, poput svih žitarica, sadrži malu količinu lipida (2-3\%) (Nielsen i Hansen, 2008.), dok klica sadrži najveći dio lipida (11\%) (Šramková i sur., 2009.). Promjene u lipidima zrna pšenice tijekom skladištenja imaju važnu ulogu u pekarskoj industriji (Arya i Parihar, 1981.). Tijekom skladištenja povećava se ukupna kiselost zrna pšenice te koncentracija slobodnih masnih kiselina (Baik i Donelson, 2018.), a Baik i Donelson (2018.) kao vjerojatni razlog navode hidrolizu (razgradnju) lipida koju katalizira enzim lipaza. Uz povećanje kiselinskog stupnja, kao posljedica kvarenja lipida zrna i brašna javlja se užegli miris ili gorak okus brašna (Petrović, 2014.; Salmon, 1998.).

Povećanje kiselosti može biti uzrokovano povećanjem koncentracije slobodnih masnih kiselina i fosfata rezultirajući kvarenjem zrna kao i prisutnošću kiselih nusprodukata iz Maillardove reakcije (Strelec i sur., 2010.). Strelec i sur. (2010.) navode u svom istraživanju kako do značajnog povećanja koncentracije slobodnih masnih kiselina dolazi prvih 30 dana bez obzira na skladišne uvjete. Nakon toga perioda stupanj kiselosti se i dalje povećava, ali ne u tolikoj mjeri. 
Katarina Kurtović i sur.: Promjene u kemijskom sastavu i reološkim svojstvima pšenice tijekom skladištenja

Promjene u hektolitarskoj masi

Hektolitarska masa $\left(\mathrm{kg} \mathrm{hL}^{-1}\right)$ pokazatelj je fizikalne kakvoće zrna koja se upotrebljava kao približna mjera za očekivani prinos brašna (Karaoğlu i sur., 2010.; Kibar, 2015.). Ako je hektolitarska masa pšenice veća, može se očekivati veći prinos i kvaliteta brašna (Karaoğlu i sur., 2010.). Kibar (2015.) u svom istraživanju navodi da se hektolitarska masa dviju sorata pšenice nakon 180 dana skladištenja smanjila, što autor objašnjava mogućom promjenom u vlazi zrna (smanjenje ili povećanje) tijekom prije navedenog perioda skladištenja. Smanjenje u hektolitarskoj masi većinom je povezano sa gustoćom zrna tijekom skladištenja (Kibar, 2015.). Prema Strelecu i sur. (2010.), tijekom jednogodišnjeg skladištenja pri $45 \%$ relativne vlage zraka i različitim temperaturama skladištenja došlo je do neznatnog smanjenja hektolitarske mase sorata pšenice Žitarka $\left(40^{\circ} \mathrm{C}\right.$ : za $1.0 \mathrm{~kg} / \mathrm{hL}, 25^{\circ} \mathrm{C}: 0.7 \mathrm{~kg} / \mathrm{hL}$ te $4^{\circ} \mathrm{C}$ : $0.4 \mathrm{~kg} / \mathrm{hL})$ i Srpanjka $\left(40^{\circ} \mathrm{C}\right.$ : za $0.9 \mathrm{~kg} / \mathrm{hL}, 25^{\circ} \mathrm{C}: 0.7 \mathrm{~kg} / \mathrm{hL}$ te $\left.4^{\circ} \mathrm{C}: 0.3 \mathrm{~kg} / \mathrm{hL}\right)$. Autori objašnjavaju kako na nekim sortama, pogotovo onima visoke kvalitete kao što je sorta Divana (tzv. "poboljšivač") nije bilo značajnih promjena u hektolitarskoj masi tijekom skladištenja.

Promjene u reološkim svojstvima i svojstvima mljevenja tijekom skladištenja

Određivanje reoloških svojstava tijesta dobar je način ocjenjivanja kvalitete brašna jer može otkriti svojstva tijesta tijekom procesa obrade, te ukazati na kvalitetu konačnog proizvoda (Hadnađev i sur., 2015.). Količina i kompozicija proteina su čimbenici koji utječu na reološka svojstva pšenice i njezina pekarska svojstva (Hadnađev i sur., 2015.). Čimbenici koji utječu na pekarsku kvalitetu pšenice i pšeničnog brašna su: klimatski uvjeti na polju, genotip te uvjeti tijekom skladištenja (Hrušková i Machová, 2002.). Farinograf, ekstenziograf, valorigraf i mikso-graf su specijalni instrumenti pomoću kojih se može odrediti i usporediti reološka svojstva različitih tijesta (Díosi i sur., 2015.; Berland i Launday, 1995.). Tijekom posliježetvenog dozrijevanja reološka svojstva se mijenjaju, odnosno tijesto pšenice koja je dulje uskladištena postaje elastičnije i manje rastezljivo u odnosu na tijesto i reološka svojstva pšenice odmah nakon žetve. Promjene viskoelastičnih svojstava tijesta od slabijeg brašna tijekom skladištenja jače se očituju (Hadnađev i sur., 2015.;). Tijekom skladištenja brašna odvijaju se složeni biokemijski procesi koji započinju nakon mljevenja i traju približno tri tjedna. Utvrđeno je kako je važno da brašno bude uskladišteno određeno vrijeme jer se time osigurava optimalna pekarska kakvoća, koja je pod 
Katarina Kurtović i sur.: Promjene u kemijskom sastavu i reološkim svojstvima pšenice tijekom skladištenja

utjecajem svojstava brašna te uvjeta u kojima je brašno uskladišteno (Hadnađev i sur., 2015.). Kamboj i sur. (2017.) istraživali su utjecaj triju uvjeta skladištenja zrna pšenice na svojstva tijesta pripravljena od brašna navedenih uzorka pšenice. Pšenica je skladištena tijekom šest mjeseci na tri različite temperature: $20^{\circ} \mathrm{C}, 4^{\circ} \mathrm{C}$ i sobna temperatura. Utvrdili su kako je tijesto pripravljeno od zrna pšenice koje je skladišteno pri $20^{\circ} \mathrm{C}$ imalo najveću elastičnost. Miličević i sur. (2009.) su u svom istraživanju utvrdili kako je skladištenje brašna pripravljenog od cijelog zrna pšenice pri $4^{\circ} \mathrm{C}$, poboljšalo volumen kruha.

Različiti autori navode kako se kvaliteta te svojstva mljevenja i pečenja poboljšavaju, nakon što su brašno ili požeta pšenica skladišteni određeno vrijeme. Isti autori također navode da se kvaliteta pšenice ne mijenja nekoliko godina, a zatim dolazi do pogoršavanja (Wang i Flores, 1999.; Ariyama i Khan, 1990.). Iz istraživanja koje su proveli Srivastava i Rao (1994.), utvrđeno je da je došlo do pogoršanja kvalitete kruha nakon što je pšenice bila uskladištena pet mjeseci pri temperaturi od $50^{\circ} \mathrm{C}$. Hadnađev i sur. (2015.) su skladištili zrno pšenice tijekom 50 dana pri $22^{\circ} \mathrm{C}$ i $70 \%$ relativne vlage zraka. Nakon 50 dana skladištenja utvrdili su povećanje u HMW (high molecule weight) glutenina kod dvije od tri istraživane sorte. Neki autori ističu da se mljevenjem svježe pšenice odmah nakon žetve, za razliku od skladištene pšenice, postiže manji postotak izbrašnjavanja, teže mljevenje zrna i lošija svojstva pečenja tijesta (Ariyama i Khan 1990.; Salmon, 1998.). Prema nekima, veći postotak izbrašnjavanja može biti posljedica boljeg odvajanja slojeva sjemenog omotača od endosperma što, između ostaloga, ovisi o biomehaničkim svojstvima omotača zrna pšenice (Salmon, 1998.; Hourston i sur., 2017.). Posner i Deyoe (1986.) navode kako se u industrijji ponekad "nova", tek požnjevena pšenica čuva 2-3 mjeseca prije mljevenja ili se miješa sa 5-15 \% "stare" pšenice kako bi se postigla poželjna svojstva mljevenja i pečenja. Nakon dva mjeseca uskladištenja australske pšenice, istraživanje je pokazalo kako nije došlo da značajnih promjena u kakvoći (Wang i Flores, 1999.). Međutim, došlo je do blagog povećanja vrijednosti ocjene kvalitete kruha (Wang i Flores, 1999.). U tablici 2 nalaze se podaci o promjenama u vrijednosti kruha s obzirom na broj dana skladištenja pšenice koje su pripremili Wang i Flores (1999). Volumen kruha dosegao je maksimum kada je pšenica bila uskladištena 4 ili 5 mjeseci. 
Katarina Kurtović i sur.: Promjene u kemijskom sastavu i reološkim svojstvima pšenice tijekom skladištenja

Tablica 2. Utjecaj duljine trajanja skladištenja pšenice na volumen kruha

Table 2 Effect of length of wheat storage on bread volume

\begin{tabular}{|l|c|c|}
\hline \multirow{4}{*}{ Izvor } & Volumen kruha & $\begin{array}{c}\text { Trajanje skladištenja pšenice } \\
\text { (broj dana) }\end{array}$ \\
\hline \multirow{4}{*}{ Rao i sur. (1978.) } & $1.7 \mathrm{~cm}^{3} / \mathrm{g}$ & 0 \\
\cline { 2 - 3 } & 1.8 & 30 \\
\cline { 2 - 3 } & 2.0 & 60 \\
\cline { 2 - 3 } & 2.5 & 90 \\
\hline \multirow{4}{*}{ Posner i Deyoe (1986) } & 3.0 & 120 \\
\cline { 2 - 3 } & $836 \mathrm{cc}$ & 21 \\
\cline { 2 - 3 } & 856 & 42 \\
\cline { 2 - 3 } & 862 & 63 \\
\cline { 2 - 3 } & 884 & 84 \\
\cline { 2 - 3 } & 875 & 105 \\
\cline { 2 - 3 } & 925 & 126 \\
\hline \multirow{3}{*}{ Ariyama i Khan (1990) } & 855 & 30 \\
\cline { 2 - 3 } & $785 \mathrm{cc}$ & 120 \\
\cline { 2 - 3 } & 810 & 240 \\
\cline { 2 - 3 } & 880 & 150 \\
\hline
\end{tabular}

Izvor: Wang i Flores (1999)

\section{ZAKLJUČAK}

Posliježetveno dozrijevanje pšenice počinje odmah nakon žetve, te se nastavlja u skladištu. Čimbenici koji utječu na trajanje i kvalitetu posliježetvenog dozrijevanja zrna su: kultura (vrsta), genotip, relativna vlaga zraka, temperatura zraka u skladištu, mikoroorganizmi, insekti, svjetlost, te uvjeti u objektima u kojima se skladišti pšenica. Tijekom posliježetvenog dozrijevanja u skladištu u pšenici dolazi do smanjenja hektolitarske mase i sedimentacijske vrijednosti, do povećanja broja padanja i vlažnog glutena, do povećanja ili smanjenja indeksa glutena te do smanjenja određenih reoloških svojstava u roku od godine dana. Reološka svojstva tijesta ovise o omjeru SS / SH grupa proteina brašna. Kvaliteta te svojstva mljevenja i pečenja poboljšavaju se nakon posliježetvenog dozrijevanja pšenice, dok je brzina promjene u kvaliteti pšenice sporija pri nižoj vlazi i temperaturi. Iz svega navedenog može se zaključiti da je proces posliježetvenog dozrijevanja kompleksan proces, te je potrebno poznavati različite čimbenike i njihovo međusobno djelovanje. 
Katarina Kurtović i sur.: Promjene u kemijskom sastavu i reološkim svojstvima pšenice tijekom skladištenja

\section{LITERATURA}

1. Angelo A.J.St., Ory R.L. (1983.): Lipid degradation during seed deterioration. Symposium: Deterioration mechanisms in seed. The American Phytopathological Society. 73(2): 315-317.

2. Anjum F.M., Walker C.E. (2000.). Grain, flour and bread-making properties of eight Pakistani hard white spring wheat cultivars grown at three different locations for 2 years. International Journal of Food Science and Technology, 35: 407-416.

3. Ariyama T., Khan K. (1990.): Effect of laboratory sprouting and storage on physiochemical and breadmaking properties of hard red spring wheat. Cereal Chem. 67(1): 53-58.

4. Arya S.S., Parihar D.B. (1981.): Effect of moisture and temperature on storage changes in lipids and carotenoids of atta (wheat flour). Die Nahrung, Chemie, Biochemie, Mikrobiologie, Technologie, Ernahrung. 2: 121-126.

5. Baik B-K., Donelson T. (2018.): Postharvest and postmilling changes in wheat grain and flour quality characteristics. Cereal Chemistry, 00: 1-8.

6. Belderok B., Mesdag H., Donner D.A. (2000.): Bread-Making Quality of Wheat. Springer, New York. str. 31.

7. Berland S., Launay B. (1995.): Rheological properties of wheat flour doughs in steady and dynamic shear: Effect of water content and some additives. Cereal Chem. 72(1):48-52.

8. Cauvain P.S. (2003.): Bread Making: Improving Quality. Woodhead Publishing Limited, Cambidge, 432-433.

9. Corona-Carrillo J. I., Flores-Ponce M., Chávez-Nájera G., Díaz-Pontones D. M. (2014.): Peroxidase activity in scutella of maize in association with anatomical changes during germination and grain storage. Springerplus, 3: 399.

10. Ćurić D., Karlović D., Tušak D., Petrović B., Đugum J. (2001.): Gluten as a standard of wheat flour quality. Food Technol. Biotechnol. 39(4): 353-361.

11. Dave R.H. (2008.): Overview of pharmaceutical excipients used in tablets and capsules. Drug Topics, Available at:

http://www.drugtopics.com/hospitalhealth-system-pharmacy/overviewpharmaceutical-excipients-used-tablets-and-capsules

12. Delcour J.A., Joye I.J., Pareyt B., Wilderjans E., Brijs K., Lagrain B. (2012.): Wheat gluten functionality as a quality determinant in cereal-based food products. Annu Rev Food Sci Technol. 3:469-92. 
Katarina Kurtović i sur.: Promjene u kemijskom sastavu i reološkim svojstvima pšenice tijekom skladištenja

13. Díosi G., Móré M., Sipos P. (2015.): Role of the farinograph test in the wheat flour quality determination. Acta Universitatis Sapientiae, Alimentaria., 8(1): 104-110.

14. Ephrat J., Sinmena B. (1976): Storage duration and temperature, and wheat genotype effect on sedimentation value. Agronomy Journal. 68: 27-30.

15. FAO (2011.): Rural structures in the tropics. Design and development. Rome. 363-386. Available at: http://www.fao.org/docrep/015/i2433e/i2433e00.htm

16. FAOSTAT (2016.): http://www.fao.org/faostat/en/\#data/QC

17. Grains Research \& Development Corporation (2011.): Grain storage - fact sheet. https://agridrydryers.com/wp-content/uploads/2019/01/Dealing-withHigh-Moisture-Grain.pdf

18. Györi Z. (2005.): Sulphur content of winter wheat grain in long term field experiments. In: Jornual: Communications Soil Science and Plant Analysis. 36(1-3), 373-382.

19. Hadnađev M., Dapčević Hadnađev T., Pojić M., Torbica A., Tomić J., Rakita S., Janić Hajnal E. (2015.): Changes in the rheological properties of wheat dough during short-term storage of wheat. Journal of the Science of Food and Agriculture. 95(3): 569-575.

20. Heyne E.G. (1987.): Wheat and Wheat Improvement, Agronomy Monograph 13, American Society of Agronomy, Inc., Crop Science Society of America, Inc., Soil Science Society of America

21. Horváthová V., Janeček Š., Šturdík E. (2000.): Amylolytic enzymes: their specificities, origins and properties. Biologia, Bratislava, 55/6: 605-615.

22. Hourston J. E., Ignatz M., Reith M., Leubner-Metzger G., Steinbrecher T. (2017.): Biomechanical properties of wheat grains: the implications on milling. J R Soc Interface, 14(126): 20160828.

23. Hrušková M., Machová D. (2002.): Changes of wheat flour properties during short term storage. Czech J Food Sci. 20(4):125-130.

24. Hrušková M., Škodová V., Blažek J. (2004.): Wheat sedimentation values and falling number. Czech J. Food Sci. 22 (2): 51-57.

25. Ji, T., \& Baik, B.-K. (2016.). Storage conditions affecting increase in falling number of soft red winter wheat grain and the impact on $\alpha$-amylase activity. Cereal Chemistry, 93, 263-267.

26. Kamboj U., Guha P., Mishra S. (2017.): Changes in rheological properties of wheat due to storage. Journal of the Science of Food and Agriculture, 98(4): $1374-1380$. 
Katarina Kurtović i sur.: Promjene u kemijskom sastavu i reološkim svojstvima pšenice tijekom skladištenja

27. Karaoğlu M.M., Aydeniz M., Kotancilar H.G., Gerçelaslan K.E. (2010.): A comparison of the functional characteristics of wheat stored as grain with wheat stored in spike form. Int. J. Food Sci. Tech. 45(1): 38-47.

28. Khademi M. (1990.): Storage protein degradation and proteolytic enzyme activities during germination of water stressed impatiens seeds. Iowa State University Digital Repository. Available at:

http://lib.dr.iastate.edu/cgi/viewcontent.cgi?article=10377\&context=rtd

29. Kibar H. (2015.): Influence of the storage conditions on quality properties of wheat varieties. Journal of Stored Products Research. 62: 8-15.

30. Mezei Z., Sipos P., Győri Z. (2007.): Variations in quality parameters of forage and medium quality of winter wheat varieties in storage. Agriculturae Conspectus Scientificus. 72(3): 221-225.

31. Mhiko T.A. (2012.): Determination of the causes and the effects of storage conditions on the quality of silo stored wheat (Triticum aestivum) in Zimbabwe. Nat. Prod. Bioprospect. 2: 21-28.

32. Miličević D., Selimović A., Pešić T., Hodžić H., Aljić M. (2009.): A baking function depending upon storage condition and a type of flour. Agriculturae Conspectus Scientificus, 7483): 243-247.

33. Móré M., Diósi G., Sipos P., Győri Z. (2015.): Investigation of rheological properties of winter wheat varieties during storage. Acta Univ. Sapientiae, Alimentaria, 8:63-69.

34. Niaz I., Dawar S., Sitara U. (2011.): Effect of different moisture and storage temperature on seed borne mycoflora of maize. Pak. J. Bot. 43(5): 2639-2643.

35. Nielsen M.M., Hansen Å. (2008.): Stability of Vitamin E in Wheat Flour and Whole Wheat Flour During Storage. Chereal Chem. 85(6): 716-720.

36. Oikonomou N.A., Bakalis S., Rahman M.S., Krokida M.K. (2015.): Gluten index for wheat products: main variables in affecting the value and nonlinear regression model. Food Science and Nutrition. 18:1-11.

37. Peterson M.E., Daniel R.M., Danson M.J., Eisenthal R. (2007.): The dependence of enzyme activity on temperature: determination and validation of parameters. Biochem J. 402(Pt 2): 331-337.

38. Petrović M. (2014.): Promjene kvalitativnih svojstava čajnog peciva od pšeničnog brašna nakon skladištenja. Sveučilište Josipa Jurja Strossmayera u Osijeku|Prehrambeno - tehnološki fakultet Osijek, diplomski rad, Osijek. Available at: https://repozitorij.ptfos.hr/islandora/object/ptfos:139/preview

39. Pomeranz Y. (1968.): Relation between chemical composition and breadmaking potentialities of wheat flour. Advances in Food Research, 16: 335-455. 
Katarina Kurtović i sur.: Promjene u kemijskom sastavu i reološkim svojstvima pšenice tijekom skladištenja

40. Posner E.S., Deyoe C.W. (1986.): Changes in milling properties of newly harvested hard wheat during storage. Cereal Chem. 63(5):451-456.

41. Rao, V. S., Vakil, U. K. and Sreenivasan, A. (1978.): Comparative studies on physicochemical and baking properties of newly harvested and stored Indian varieties of wheat. J. Sci. Fd Agric. 29: 155-164.

42. Rasheed A., Xia X., Yan Y., Appels R., Mahmood T., He Z. (2014): Wheat seed storage proteins: Advances in molecular genetics, diversity and breeding applications. Journal of Cereal Science 60:11-24.

43. Ritz, J. (1992.): Osnovi uskladištenja ratarskih proizvoda, Agronomski fakultet. Zagreb

44. Roberts, E.H., (1972.): Loss of viability and crop yield. In: Viability of Seeds, Roberts, E.H. (Ed.). Chapman and Hall, London, 79-80.

45. Salmon S.E. (1998.): Effects of seasonal and short-term changes during storage on the breadmaking performance of home-grown wheat. HGCA. Project report. No. 160.

46. Salunkhe D.K., Deshpande S.S. (1991.): Foods of plant origin: Production, Technology, and Human Nutrition. Springer Science+Business Media New York, LLC.

47. Sawant A.A., Patil S.C., Kalse S.B., Thakor N.J. (2012.): Effect of temperature, relative humidity and moisture content on germination percentage of wheat stored in different storage structures. Agricultural Engineering International: CIGR Journal. 14(2): 110-118.

48. Shevkani K., Singh N., Bajaj R., Kaur A. (2016.): Wheat starch production, structure, functionality

49. Shewry P.R., Tatham A.S. (1997.): Disulphide bonds in wheat gluten proteins. Journal of Cereal Science, 25: 207-227.

50. Sivam A.S., Sun-Waterhouse D., Quek S., Perera C.O. (2010): Properties of bread dough with added fiber polysaccharides and phenolic antioxidants: a review. J Food Sci. 75(8): R163-R174.

51. Sorour H., Uchino T. (2004.): The effect of storage condition on the respiration of soybean. Journal of JSAM 66 (1): 66-74.

52. Srivastava A.K., Haridas-Rao P. (1994.): Changes in the functional characteristics of wheat during high temperature storage. Journal of Food Science \& Technology. 31(1): 36-39.

53. Strelec I., Koceva Komlenić D., Jurković V., Jurković Z., Ugarčić-Hardi Ž., Sabo M. (2010.): Quality parameter changes in wheat varieties during storage at four different storage conditions. Agriculturae Conspectus Scientificus. 75(3): 105-111. 
Katarina Kurtović i sur.: Promjene u kemijskom sastavu i reološkim svojstvima pšenice tijekom skladištenja

54. Šramková Z., Gregová E., Šturdík E. (2009.): Chemical composition and nutritional quality of wheat grain. Acta Chimica Slovaca. 2(1): 115 - 138.

55. Tomić J., Pojić M., Torbica A., Rakita S., Živančev D., Janić Hajnal E., Dapčević Hadnađev T., Hadnađev M. (2013.): Changes in the content of free sulphydryl groups during postharvest wheat and flour maturation and their influence on technological quality. Journal of Cereal Science. 58(3): 495-501.

56. Veraverbeke W.S., Delcour J.A. (2002.): Wheat protein composition and properties of wheat glutenin in relation to breadmaking functionality. Critical Reviews in Food Science and Nutrition. 42: 179-208.

57. Wang L., Flores R. A. (1999.): The effects of storage on flour quality and baking performance. Food Rev. Int. 15(2): 215-234.

58. Zhou A., Robards K., Helliwell S., Blanchard C., Baxterb C. (2003.): Rice ageing. I. Effect of changes in protein on starch behaviour. Starch/Stärke, 55: $162-169$.

59. http://www.aelab.co.za/index.php/perten/135

60. https://www.perten.com/Products/Falling-Number/Applications/Flour-millingand-baking/

61. https://www.grainscanada.gc.ca/fact-fait/gluten-eng.htm

Adresa autora - Author's address:

Katarina Kurtović, univ.bacc.ing.agr, studentica,

Ana Matković, mag.ing.agr.,

Izv. prof. dr. sc. Željko Jukić, e-mail: zjukic@agr.hr

Sveučilište u Zagrebu, Agronomski fakultet,

Zavod za specijalnu proizvodnju bilja,

Svetošimunska cesta 25, 10000 Zagreb

Karmen Jukić, dipl.ing.

BELJE d.d. PC TSH PJ Mlin Križevci,

Bjelovarska 1048260 Križevci
Primljeno- Received:

15.11.2018. 
402 